\title{
Archaeological Survey of the Proposed Uvalde Sanitary Landfill Area, Uvalde County, Texas
}

H. Ray Smith

Follow this and additional works at: https://scholarworks.sfasu.edu/ita

Part of the American Material Culture Commons, Archaeological Anthropology Commons, Environmental Studies Commons, Other American Studies Commons, Other Arts and Humanities Commons, Other History of Art, Architecture, and Archaeology Commons, and the United States History Commons

Tell us how this article helped you.

This Article is brought to you for free and open access by the Center for Regional Heritage Research at SFA ScholarWorks. It has been accepted for inclusion in Index of Texas Archaeology: Open Access Gray Literature from the Lone Star State by an authorized editor of SFA ScholarWorks. For more information, please contact cdsscholarworks@sfasu.edu. 


\section{Archaeological Survey of the Proposed Uvalde Sanitary Landfill Area, Uvalde County, Texas}

\section{Creative Commons License}

\section{(c) (1) (8)}

This work is licensed under a Creative Commons Attribution-NonCommercial 4.0 International License 


\section{ARCHAEOLOGICAL SURVEY OF THE \\ PROPOSED UVALDE SANITARY LANDFILL AREA, \\ UVALDE COUNTY, TEXAS}

H. Ray Smith

Texas Antiquities Committee Permit No. 511

Thomas R. Hester, Principal Investigator

Center for Archaeological Research The University of Texas at San Antonio ${ }^{(1}$ Archaeological Survey Report, No. 154 
The following information is provided in accordance with General Rules of Practice and Procedure, Chapter 41.11 (Investigative Reports), Texas Antiquities Committee:

1. Type of Investigation: Archaeological survey;

2. Project Name: Uvalde Sanitary Landfi11;

3. County: Uvalde County, Texas;

4. Principal Investigator(s): Dr. Thomas R. Hester, Principal Investigator, and Jack D. Eaton, Co-Principal Investigator;

5. Name and Location of Sponsoring Agency: W. He Mullins, Inc.s Consulting Engineers;

6. Texas Antiquities Committee Permit No. 511;

7. Published by the Center for Archaeological Research, The University of Texas at San Antonio, San Antonio, Texas 78285, 1986.

A 1 ist of publications offered by the Center for Archaeological Research can be obtained by sending $\$ 1.00$ to the Center for Archaeological Research. The University of Texas at San Antonio, San Antonio, Texas 78285. 


\section{ABSTRACT}

During May 1985, the Center for Archaeological Research, The University of Texas at San Antonio, under contract with W. H. Mul1ins, Inc., Consulting Engineers, conducted a 100\% archaeological survey at the proposed Uvalde Sanitary Landfill area located on the Kellogg and Rodriguez leases approximately 3.8 miles southwest of Uvalde, Texas. The area is 1 ocated adjacent to FM481.

The Rodriguez 1ease (63 acres) yielded one isolated artifact (Clear Fork tool). No other cultural materials were observed.

The Kellogg lease (63 acres) yielded one isolated artifact (end and/or side scrapery. In addition, a smal1 area of 1 ithic scatter was observed in the northeast corner of the property. Shovel tests throughout the area failed to produce any subsurface cultural material.

The cultural resources found within the survey area are determined not to be significant, and therefore not eligible for nomination to the National Register of Historic Places or to be 1 isted as a State Archeological Landmark. We recommend that no further work is needed. 
TABLE OF CONTENTS

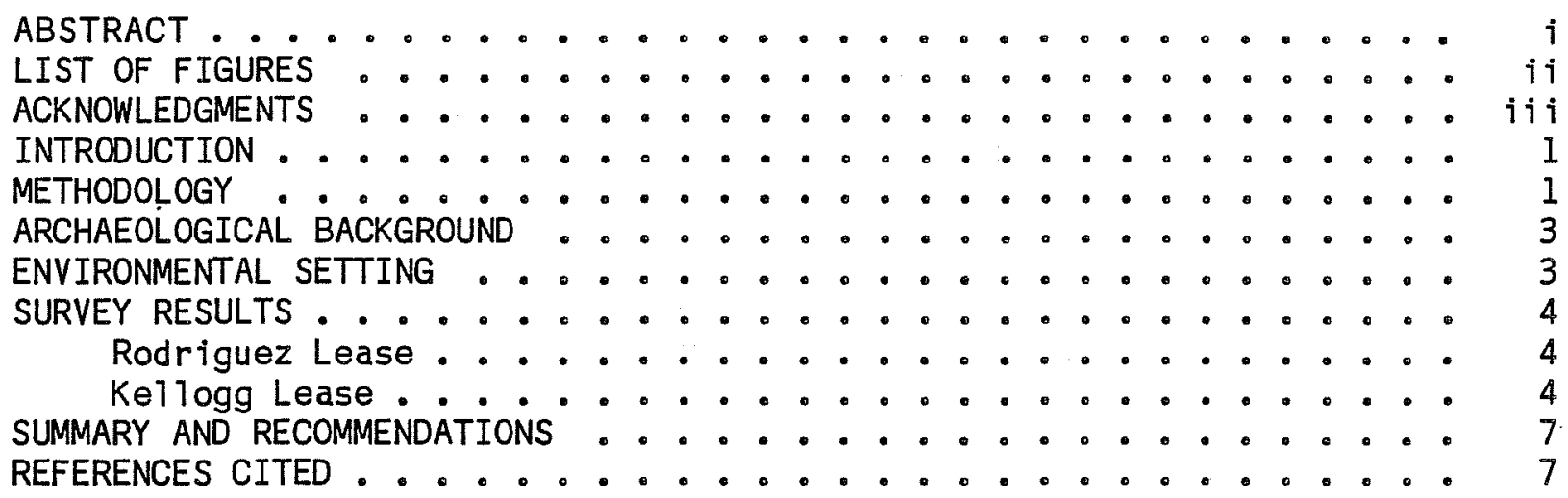

\section{LIST OF FIGURES}

1. Location of City of Uvalde Proposed Sanitary Landfill . . . . . 2

2. The Kellogg and Rodriguez Leases ............. 5

3. Isolated Artifacts Collected ............... 6 


\section{ACKNOWLEDGMENTS}

Mr. Ron G. Hughes, P.E., of W. H. Mul 1 ins, Inc., and Mr. James Thurman, City Manager of Uvalde, Texas, were helpful in providing maps and other information essential to complete this survey.

Mr. William P. Kellogg and Mr. Rodrigo G. Rodriguez visited the survey areas and provided first hand information and history of their respective leases.

The field work was accomplished with the assistance of Ralph Snavely from the Center for Archaeological Research, The University of Texas at San Antonio, and Lenora Metting and Sarah Schwartz from the Southern Texas Archaeological Association.

I am grateful to the Center for Archaeological Research office staff, for their aid in preparing this manuscript. 



\section{INTRODUCTION}

During May 4 and 5, 1985, the Center for Archaeological Research (CAR), The University of Texas at San Antonio (UTSA), conducted a $100 \%$ surface survey of 126 acres (51 hectares) proposed for the Uvalde Sanitary Landfil1. The area is approximately $3.8 \mathrm{miles}(6.08 \mathrm{~km})$ southwest of Uvalde, Texas, and adjacent to FM481 (Fig. 1). Two adjoining leases (the Kellogg and Rodriguez leases) were surveyed, each consisting of 63 acres (25.5 hectares). The survey was done under contract between W. H. Mul1ins, Inc., Consulting Engineers for the City of Uvalde and the Center for Archaeological Research. The University of Texas at San Antonio (1etter dated Apri1 1, 1985). The archaeological survey was part of the study undertaken by W. H. Mul1ins, Inc., for the City of Uvalde to determine if the properties would be suitable for a proposed 1andfi11. The City of Uvalde has lease arrangements with the 1andowners.

The field work was conducted by H. Ray Smith, assisted by Ralph Snavely (both CAR Technical Staff Assistants) and Lenora Metting and Sarah Schwartz (both of the Southern Texas Archaeological Association). Overall supervision was provided by Dr. Thomas R. Hester, Director of the Center and principal investigator, and Jack D. Eaton, Associate Director and co-principal investigator.

The work was done in order to assess eligibility qualifications for nomination to the National Register of Historic Places in accordance with the National Historic Preservation Act of 1966, as amended, and Executive Order 11593. The survey was conducted under Texas Antiquities Committee Permit No. 511 .

\section{METHODOLOGY}

Research methodology for the $100 \%$ surface survey and assessment of the proposed 1 andfill area followed the "Guidelines for Curation Standards and Procedures" (CTA 1981) and "Field Methods in Archaeology" (Hester, Heizer, and Graham 1975).

Field operations consisted of a series of transects spaced to give effectively $100 \%$ coverage across the properties with emphasis on identification of any cultural resources and the recording and collection of any diagnostic or significant materials. USGS $1: 24,000$ scale topographic maps were used, along with the $I^{\prime \prime}=100$ 'scale 1 andf $i 11$ construction maps and $I^{\prime \prime}=200^{\prime}$ scale drainage maps prepared and supplied by W. H. Mul1 ins, Inc., Consulting Engineers. The survey recorded elevations, soil types, area vegetation, distance to water source, and other specific area information.

No archaeological sites were found. The only cultural materials found and collected were two isolated artifacts. These were plotted on the area map, photographed, and placed in plastic bags and 1 abeled as to location, date, name of collector, and other pertinent information. Field notes and artifacts are on file at the Center for Archaeological Research, The University of Texas at San Antonio. 


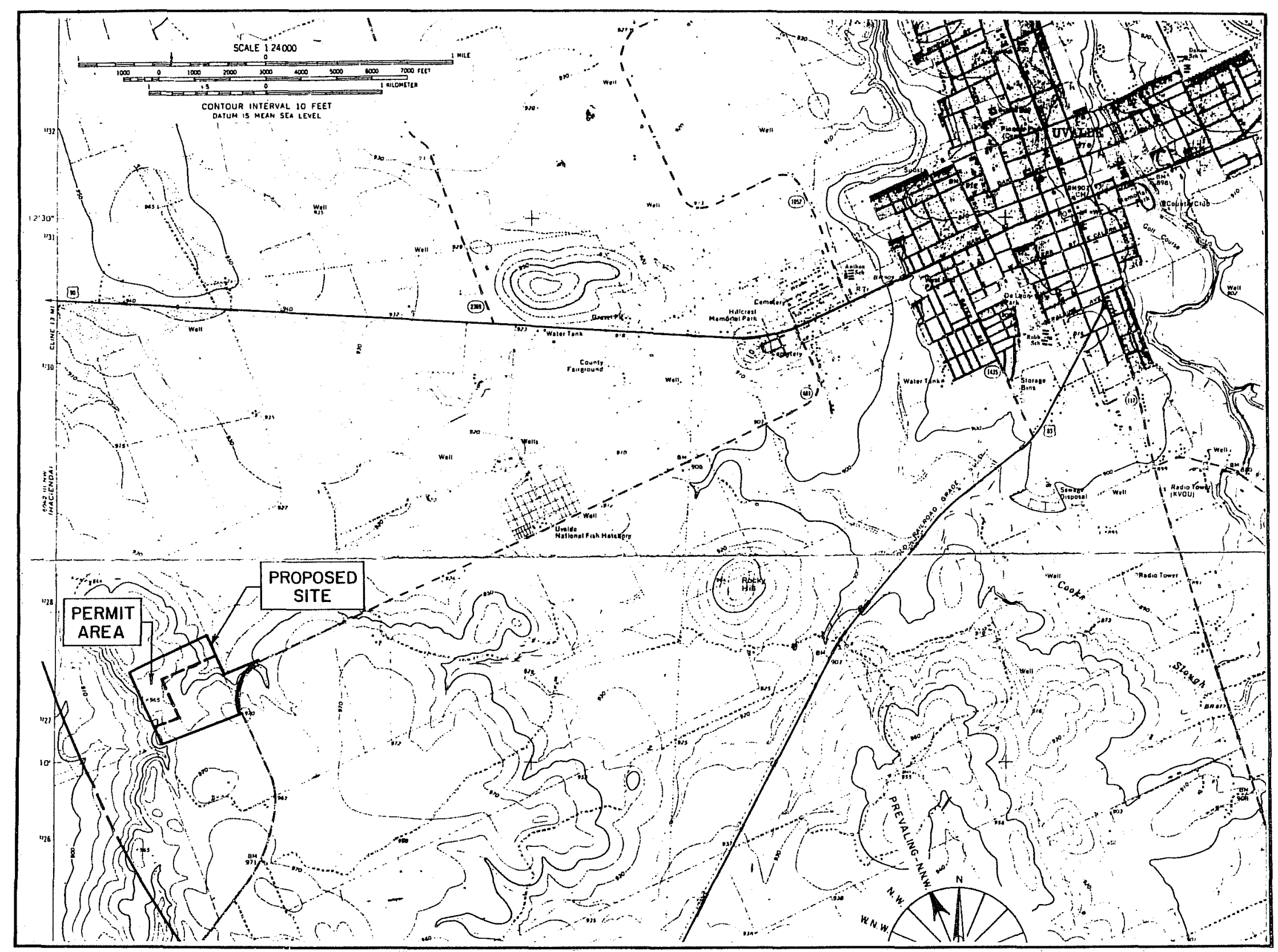

Figure 1. Location of City of Uvalde Proposed Sanitary Landffll. 
ARCHAEOLOGICAL BACKGROUND

The Uvalde County area has been utilized by hunting and gathering Indian groups for over 10,000 years. The chronological cultural sequence recognized for this area is as follows: the Paleo-Indian (10,000 B.C. to 6000 B.C.), the Archaic (6000 B.C. to A.D. 1000), the Late Prehistoric (A.D. 1000 to A.D. 1600), and the Historic (after A.D. 1600).

Prehistoric sites investigated in Uvalde County include the Monte 11 Rockshelter (41 UV 3; Evans 1947) in the northwestern part of the county and the Kincaid Rockshelter (41 UV 2; Suhm 1960) in the eastern part of the county. Both shelters revealed Paleo-Indian and Archaic materials. In the Montel1 Rockshelter there is a panel of images approximately $2.5 \mathrm{~m}$ high by $16 \mathrm{~m}$ long. Portions of the pictographs have been recorded by $T$. R. Hester and by the author (notes on file). The "G" Rockshelter (41 UV 121) in the same area was recorded by Smith and Nelson in 1983 (notes on file). The Whites Mine Rockshe1ter, which has very faded images, was recorded by the author in 1983 (notes on $\mathrm{file}$ ). This shelter is approximately 15 miles west of the survey area. In north-central Uvalde County the Mason Ranch Burial Cave was reported by Benfer and Benfer (1981).

Burned rock middens and open campsites were recorded at the La Jita site (41 UV 21; Hester 1971), a Middle Archaic site near Utopia, Texas, and the Anthon site (4I UV 60) approximately four miles southwest of the survey area (Weir and Doran 1980). Significant Late Prehistoric and Archaic occupations were recorded from the Anthon site. Along the Leona River drainage north of Uvalde, open campsites, middens, hearths, and 1 ithic concentrations were recorded (Hal1 1974; Lukowski n.d.).

Historic sites in the area include two Spanish missions: Nuestra Señora de 1a Candelaria and San Lorenzo de 1 a Santa Cruz (Tunnel1 and Newcomb 1969) on the upper Nueces River. Fort Inge (4I UV 75) located three miles due east of the survey area is being investigated by G. Nelson and the Uvalde County Historical Commission (Nelson 1981, 1982). Nelson's 1982 report contains a summary of Spanish and French activities in the Uvalde area from 1535. A detailed account of early military occupation in the area has been documented. by Smith (1981).

\section{ENVIRONMENTAL SETTING}

The survey area is located within the Gulf Coastal Plain near the southern 1 imits of the Balcones Fault Zone in Uvalde County. Underlying the area at relatively shallow depths are the Austin Chalk. Anacacho Limestone, and Escondido formations of the Cretaceous system. Overlying these formations is the Uvalde Grave1, a Pliocene or Pleistocene Fluvial deposit. Several faults traverse the area. Geolagic evidence indicates that the movement along the faults has not occurred within the 1 ast one million years. The northern section of the area is underlaid by silty Bentonitic $\mathrm{Cl}$ ays representative of the Basal Anacacho Limestone formation. The modern ground surface consists of caliche, 1 imestone outcroppings, sand, clay, and 1 oose chert-bearing 
Uvalde Gravels mixed with numerous calcareous nodules (Stevens and Richmond 1976).

A ridge runs along the western portion of the area (Fig. 2). Surface water on the west side of the ridge drains into the $E 1 \mathrm{~m}$ Creek tributary and eventually into the Nueces River. Surface water on the east side of the ridge drains into the Leona River tributary and eventual 1 y into the Leona River. From the ridge there is a commanding view of the lower 1 ands to the north, east, and west.

The flora of the area is a mesquite and desert grass savannah with thornbush, whitebrush, native grasses, prickly pear cactus, oak, elm, hackberry, and persimmon trees.

The fauna of the area includes white-tailed deer, coyote, fox, armadil10, javel ina, squirrel, dove, quail, turkey, cottontail rabbit, jackrabbit, raccoon, and diamondback rattiesnake.

\section{SURVEY RESULTS}

\section{Bodriguez Lease}

The survey of the Rodriguez lease failed to produce significant evidence of prehistoric or historic activity. Small scatters of 1 ithic debris occurred within the survey area, but no concentrations were found (Fig. 2). One diagnostic artifact (Clear Fork tool) was recovered in a bulldozer cut (Fig. $3, a)$.

\section{Kellogg Lease}

The survey of the Kellogg lease did not produce any significant evidence of prehistoric of historic activity. However, in the northeast corner of the property a 1 ithic scatter was observed in an eroded road cut (Fig. 2). Chert flakes and smal1 burned 1 imestone rocks were found. Four shovel tests in the area were excavated to $30 \mathrm{~cm}$ in depth and screened through 1/4-inch mesh screen. No subsurface material was encountered. Located in a low area, the scatter could have washed in from the adjacent hillside or from the bordering property to the north which is out of the survey area. One isolated artifact (end and/or side scraper) was found on the lease (Figs. 2 and 3,b).

The property slopes from the west to the east and is void of vegetation except for small clumps of mesquite, whitebrush, and cactus. Chert-bearing Uvalde Gravels are exposed over most of the area. The scatter of chert flakes and burned rock fragments may have been a quarry workshop and may indicate the area was used for chert acquisition; this could also be a result of modern 1 and clearing. 
This page has been

redacted because it

contains restricted

information. 


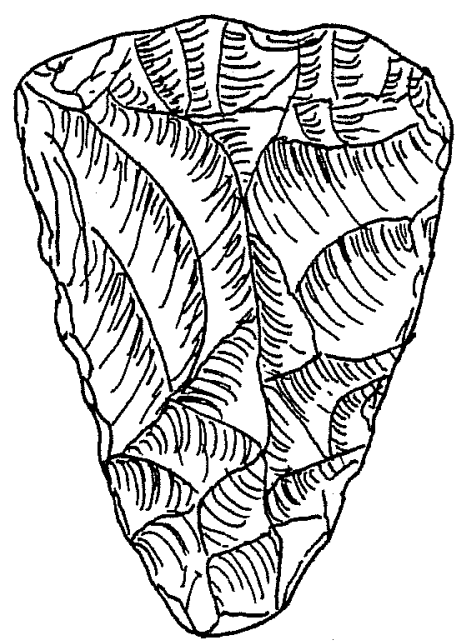

a

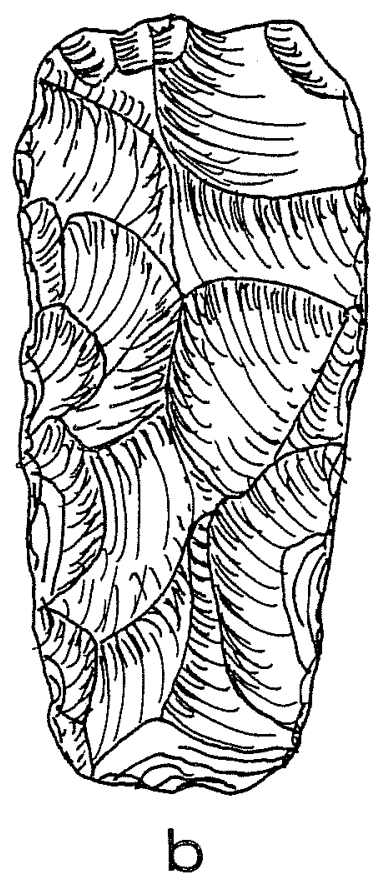

Figure 3. Isolated Artifacts Collected. a, Clear Fork tool from the Rodriguez lease; $b$, end and/or side scraper from the Kellogg lease. 
SUMMARY AND RECOMMENDATIONS

During the archaeological survey of the proposed Uvalde Sanitary Landfill area, the Rodriguez and $\mathrm{Kellogg}$ leases were carefully examined. The Rodriguez lease produced one isolated artifact (Clear Fork tool), but no archaeological sites were observed. The Kellogg lease produced one isolated artifact (end and/or side scraper), in addition to a small area of 1 ithic scatter. Shovel tests failed to produce any subsurface material.

Because of the extent of disturbance and erosion in the survey area, and the 1 ack of any potentially significant cultural deposits, no further work is recommended. However, should any cultural resources be uncovered during 1 and developments, the Texas Antiquities Committee should be notified.

\section{REFERENCES CITED}

Benfer, A. and R. Benfer

1981 The Mason Ranch Burial Cave, Uvalde County, Texas. La Tierra $8(3): 16-26$.

Council of Texas Archeologists (CTA)

1981 Guidelines for Curation Standards and Procedures. Council of Texas Archeologists, Newsletter 5(2).

Evans, G.

1947 Report on cave on the Ray Miller Ranch, Uvalde County. Texas. Manuscript dated Apri1 3, 1974, on file at the Center for Archaeological Research. The University of Texas at San Antonio.

Ha11, G. D.

1974 Leona River Watershed, UvaTde County, Texas: An Archeological and Historical Survey of Areas Proposed for Modification. Texas Archeological Survey, The University of Texas at Austin, Research Report 37.

Hester, T. R.

1971 Archeological Investigation at the La Jita Site, Uvalde County, Texas. Bulletin of the Texas Archeological Society $42: 51-148$.

Hester, T. R., R. F. Heizer, and J. A. Graham

1975 Field Methods in Archaeology. 6th Edition. Mayfield Publishing Company, Palo Alto, California. 
Lukowski, P. D.

n.d. Archaeological Investigations Along the Leona River Watershed, Uvalde County, Texas. Center for Archaeological Research. The University of Texas at San Antonio. Archaeological Survey Report 132 (in preparation).

Nelson, G.

1981 Prel iminary Archaeological Survey and Testing at Fort Inge, Texas. Uvalde County Historical Commission. Uvalde.

1982 Additional Archaeological Survey and Testing at Fort Inge, Texas. Uvalde County Historical Commission, Uvalde.

Smith, T. T.

1981 Fort Inge - A Case Study of the Texas Frontier. Manuscript on file at El Progresso Memorial Library, Uvalde, Texas.

Stevens, J.W. and D. L. Richmond

1976 Soil Survey of Uvalde County, Texas. United States Department of Agriculture, Soil Conservation Service and the Texas Agricultural Experiment Station, Washington, D.C.

Suhms D. A.

1960 A Review of Central Texas Archeology. Bulletin of the Texas Archeological Society $29: 63-107$.

Tunne 17, C. D. and W. W. Newcomb, Jr.

1969 A Lipan Apache Mission: San Lorenzo de 1 a Santa Cruz, 17621771. Texas Memorial Museum, Bulletin 14.

Weir, F. A. and G. H. Doran

1980

A Brief Report on the Anthon Site (4I UV 60). La Tierra $7(3): 17-23$. 


$$
-
$$

6 - 
